https://helda.helsinki.fi

\title{
Becoming a New Speaker of a Saami Language Through Intensive Adult Education
}

\section{Pasanen, Annika}

Multilingual matters

2019-11

Pasanen , A 2019 , Becoming a New Speaker of a Saami Language Through Intensive Adult Education . in A Sherris \& S D Penfield (eds), Rejecting the Marginalized Status of Minority Languages : Educational Projects Pushing Back Against Language Endangerment .

Multilingual matters , pp. 49-69.<

http://www.multilingual-matters.com/display.asp?isb=9781788926256 >

http://hdl.handle.net/10138/314763

acceptedVersion

Downloaded from Helda, University of Helsinki institutional repository.

This is an electronic reprint of the original article.

This reprint may differ from the original in pagination and typographic detail.

Please cite the original version. 


\section{Becoming a New Speaker of a Saami Language Through Intensive Adult Education}

Annika Pasanen

Out of the nine Saami languages still in use, three are spoken in Finland: Skolt Saami, Inari Saami (also called Aanaar Saami) and North Saami. They have different linguistic characteristics and socio linguistic backgrounds, and are endangered languages struggling to recover from generations of loss. Active revitalization of Saami languages has been ongoing since the 1990s. One of these revitalization efforts has been a fulltime, year-long adult language course. It consisted of classroom language studies, workplace language instruction, culture studies and a master-apprentice interaction with elder native speakers. This chapter provides an analysis of becoming a new speaker of a Saami language. The analysis is based on responses to survey and interview data from adult learners and their teachers, with a view to answering three research questions. (1) What are the backgrounds and motivations of the Saami language learners? (2) What examples do they report that signify use of Saami languages in domains of work, family and social networks? (3) How do adult Saami language learners (re)present their identification with L1 Saami speakers?

Já tom mun lam aaibâs vuossâmui peeivij rääjist ettâm sijjân: et tast šadda tehálumos ihe tuu elimist, taat nubástit tuu loppâeellim. [And that's what I have told them from day one: that this will become the most important year of your life, this will change the rest of your life.]

This is how Anna Morottaja, a teacher of the Aanaar Saami language prepares her students to meet the challenge of language learning: a year-long intensive language course, an academic year which potentially produces Saami-language speakers. This chapter presents an analysis of this challenge, its motivations and results.

Saami languages form a continuum of closely related languages from central Fennoscandia all the way to the east coast of the Kola Peninsula. Out of the nine Saami languages still in use, three are spoken in Finland: Skolt Saami, Aanaar Saami and North Saami. They are all separate languages with very different linguistic characteristics and socio linguistic backgrounds. All are endangered. The revitalization of endangered languages challenges former concepts and categories concerning authenticity and ownership of languages. For instance, language immersion and language education for adults have strengthened the need to describe language identities and learning processes that are not linked to learning the language at home as L1. The phenomenon of new speakers has received attention, especially in the research on emancipating and reviving some of the minority languages of Europe (O'Rourke et al., 2015). Saami languages spoken in Northern Fennoscandia are being actively revitalized, and a reversal of language shift is taking place in many Saami areas. In the research on new speakers, Saami languages have so far been considered only in a few publications (e.g. Jonsson \& Rosenfors, 2017). This chapter explores survey and interview data that were collected from adult learners and teachers of North Saami, Aanaar Saami and Skolt Saami in Finland. 
My position as a researcher is based on the fact that I am a Finnish specialist in Finno-Ugrian languages, speaking Finnish as my mother tongue. I have concentrated on northern multilingualism, endangerment and revitalization of Indigenous and minoritized languages, and I have been dealing with these issues in grassroots revitalization projects and community-based activities. I have been living in Aanaar, a municipality in the Saami region of Finland, for many years, and I have learned two Saami languages, North Saami and Aanaar Saami. Also, my Finnish children have acquired the Aanaar Saami language since their early childhood, first in a language nest and later in a school, through Aanaar Saami-medium education. This makes me both an outsider and an insider in relation to the Saami languages and communities I'm researching.

I proceed with a short overview of the historical and sociological contexts of the Saami people and languages. This is followed by a focus on the goals, methodology, data and my theoretical framework for the research. After that, I report on the backgrounds of new speakers and their language-learning process. Then I focus on the use of Saami languages after schooling, and especially the language choices of new speakers with their own children. Following this, I look at new speakers' representations of their identification with native speakers, and finally I discuss my findings in relation to a global context, raising questions for future research.

\section{Saami People and Saami Languages}

The Saami people are an arctic Indigenous people living in Finland, Sweden, Norway and the Murmansk region of the Russian Federation. The Saami languages belong to the Uralic language group, and nine Saami languages are spoken today. The similarities and differences between these languages go hand in hand with the geographic distance: speakers of neighbouring Saami languages often understand each other's language to some extent, but mutual understanding between more distant languages is more difficult. Among all Saami languages, North Saami is by far the largest, with approximately 20,00030,000 speakers in Norway, Sweden and Finland. The smallest Saami languages, like Pite Saami in Sweden and Ter Saami in Kola Peninsula, have at most a couple of dozen speakers. All the Saami languages are endangered, according to UNESCO's Atlas of the World's Languages in Danger (UNESCO, 2010), three of them critically, five of them severely and one definitely endangered.

Most of the Saami languages are currently being revitalized and strengthened, for instance through language immersion, bilingual or mother-tongue-medium education, language education for adults, Saami-language media and various language campaigns (see Aikio-Puoskari, 2016; Huss, 1999). In the global context, Saami groups living in Nordic countries have rather good possibilities for language revitalization. Saami culture in Finland, Sweden and Norway is protected by cultural autonomy, parliamentary organs, legislation and international conventions. The legal status of the Saami in the Russian Federation is considerably weaker, which adversely influences language revitalization (see Scheller, 2011).

Wide assimilation and language shift from Saami languages to Finnish is the result of various historical phases and processes, for example the Second World War, general modernization and change in the way of life of the Saami, a growing Finnish-speaking population in Saami areas, and Finnish politics concerning education. Through the boarding school system, Saami children were in many areas either 
directly or indirectly deprived of their own language and culture. The process and ideologies behind the deprivations of boarding school systems for Indigenous children are known throughout the world of Indigenous and minoritized peoples, and so are the results. A considerable proportion of the Saami who have gone through this system have chosen Finnish as the home language of their own children (Rasmus, 2008: 117).

Prerequisites of language revitalization often go hand in hand with political power, or at least political recognition. In Finland, that happened for the Saami gradually from the 1960s on. The first achievements were the instruction of Saami languages in some schools, Saami-language radio broadcasts and the establishment of the parliamentary organ of the Saami in the 1970s. In the 1990s there were legislative changes that worked in favour of Saami culture and languages which led to increasing demand for Saami languages.

This positive development enabled many of the fundamental factors of language revitalization. One of them was intensive education in Saami languages for the adult population. A year-long intensive course on Saami language and culture began in North Saami in 1999, in Aanaar Saami in 2009 and finally in Skolt Saami in 2012. These educational initiatives have produced 200-250 new speakers of these three Saami languages. While political decisions in Finland have led to legislation and financial support for Saami language revitalization, the struggles and heavy lifting of Saami activists, Saami politicians, ordinary Saami speakers and their descendants is of fundamental importance in the history of Saami revitalization. Nothing has happened without intense and sustained Saami activism (Pasanen, 2015; Seurujärvi-Kari, 2012).

Finnish national language policy is defined by the existence of two national languages in Finland: Finnish and Swedish. Their status is theoretically equal throughout the country, but in practice Finnish is dominant, although Swedish has a strong foothold in particular areas. Of the 5.5 million inhabitants, about $88 \%$ speak Finnish as a mother tongue and about 5\% Swedish. The Saami people are defined as an Indigenous people in the constitution of Finlandii. The Saami have partial autonomy in the Saami home area, which consists of the three northernmost municipalities of Finland - Enontekiö, Utsjoki and Aanaar - and a part of the municipality of Sodankylä. In this area, the Saami have a legal right to use their languages in different official domains; however, these rights are often not implemented in practice.

Another problem is that already over $60 \%$ of the Saami are living outside the official Saami areas, and their linguistic rights are rather weak there. For instance, instruction in a Saami language may be very hard to get, even for children with Saami as their mother tongue. There are approximately 10,000 Saami in Finland, and about 2000 of them have reported Saami (or one of the Saami languages) as their official mother tongue. Statistics are not very reliable in relation to the real multilingual situation among the Saami. However, current estimations of the number of speakers of different Saami languages suggest about 450 speakers of Aanaar Saami, about 300 speakers of Skolt Saami and in Finland about 1500 speakers of North Saami.

There is no universal definition of Indigeneity, but one is given in the International Labour Organization's Convention No. 169 (1989), according to which Indigenous peoples: (1) descend from populations who inhabited the country or geographical region at the time of conquest, colonization or establishment of present state boundaries; and (2) retain some or all of their own social, economic, cultural and political institutions, irrespective of their legal status iii. From this point of view, the Saami people should not be treated as a linguistic minority. However, Saami languages are everywhere endangered, marginalized 
and de facto minority languages. Terms like 'language of an Indigenous people' or 'Indigenous language' do not convey the sociological situation and power relations. That's why I use the term 'minority language' from this practical point of view, so as not to under-rate the Indigenousness of the Saami.

\section{Goals, Methods and Data}

The new speakers' role in terms of the vitality and intergenerational transmission of Saami languages is essential to the continuation of all Saami groups of Finland, but especially for the communities of Skolt and Aanaar Saami. It is therefore necessary to understand the individual process of becoming a new speaker and taking Saami language into use in different domains. In the best case, research might respond to the needs of speech communities by helping to develop intensive language education, and to support new Saami speakers in their learning process, identity and language use.

My study contributes most of all to the work done by Olthuis, Kivelä and Skutnabb-Kangas (2013), who studied the first intensive adult education course in the Aanaar Saami language (in a project called CASLE; Olthuis et al., 2013). Also, for instance, Jonsson and Rosenfors (2017) considered the issue of new speakers in their article about the language repertoire, identity and learning of a young Saami woman called Elle. Sarivaara (2012) has paid attention to this in her dissertation concerning so called non-status Saami people, who have taken a Saami language into use in their lives as a result of an individual reversing language shift.

My research questions are as follows:

- RQ1: What are the backgrounds and motivations of Saami language learners?

- RQ2: What examples do they report that signify use of Saami languages in domains of labour, family and social networks?

- RQ3: How do adult Saami language learners (re)present their identification with L1 Sami speakers?

The quantitative part of my data consists of responses to a survey and the qualitative part consists of semi-structured thematic interviews. The electronic survey resulted altogether in 85 responses from people who had studied Aanaar Saami, North Saami or Skolt Saami in a year-long intensive language course between 2009 and 2016. Of the 85 responses, 40 came from students of Aanaar Saami, 31 from students of North Saami and 14 from the students of Skolt Saami. The percentage of responses from the target group (altogether 133 students) was $64 \%$. The role of the survey was to determine: (1) the backgrounds of the students and their motivations for language learning; (2) the students' experiences of the education year and language learning process; and (3) the impact of language learning, use of Saami language in different domains, and identification with the speech community.

After the survey in spring 2017, I interviewed the teachers who taught these intensive courses. There were four at that time, of whom two were sharing the instruction of North Saami, whereas Skolt and Aanaar Saami had one teacher each. I also interviewed some of the survey respondents. This chapter draws on the data from teachers' interviews, as well as the data from the interviews of five new speakers. The new speakers had all started to use a Saami language with their children. Three of them had learned Aanaar Saami, one was a speaker of North Saami and one a speaker of Skolt Saami. The 
language of the interviews was Aanaar Saami, North Saami or Finnish, depending on the language repertoire of interviewed people and my own (in which Skolt Saami is excluded) and depending on the wishes of the interviewees. For the sake of anonymity, I refer to interviewees only as teachers or students/new speakers, not mentioning which Saami language they represent. For the same reason, I won't quote the informants in their original language but present only the English translations. One exception to this are citations of the teachers at the beginning and the end of the chapter. I also reference gender ambiguously via the use of '(s)he' because this is natural for speakers of Saami and Finnish: both languages have one pronoun for females and males.

\section{Who Wants to Learn a Saami Language and Why?}

Who are the new speakers of Saami languages in Finland? Where do they come from, and what has led them to use a whole year of their life to learn Saami? Of the 85 respondents to the survey, $35 \%$ were born in the 1980s, $20 \%$ in the 1970s, $18 \%$ in the 1990s, 15\% in the 1960 s and $12 \%$ in the 1950 s (Figure 4.1 ), and $85 \%$ were women, $15 \%$ men (Figure 4.2 ). This reflects the actual situation in the fields of learning, revitalization

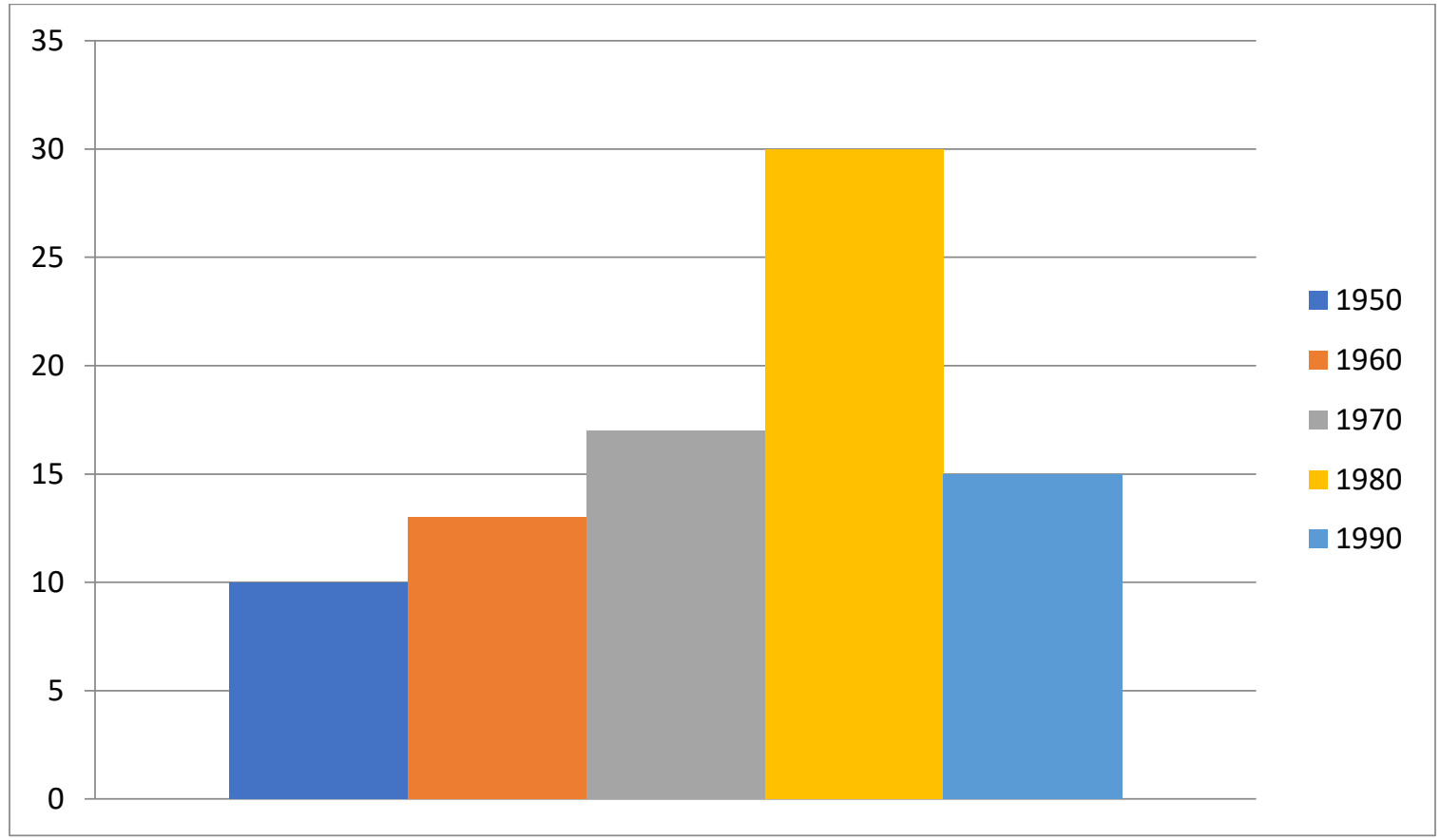

Figure 4.1 Numbers of respondents by birth decade 


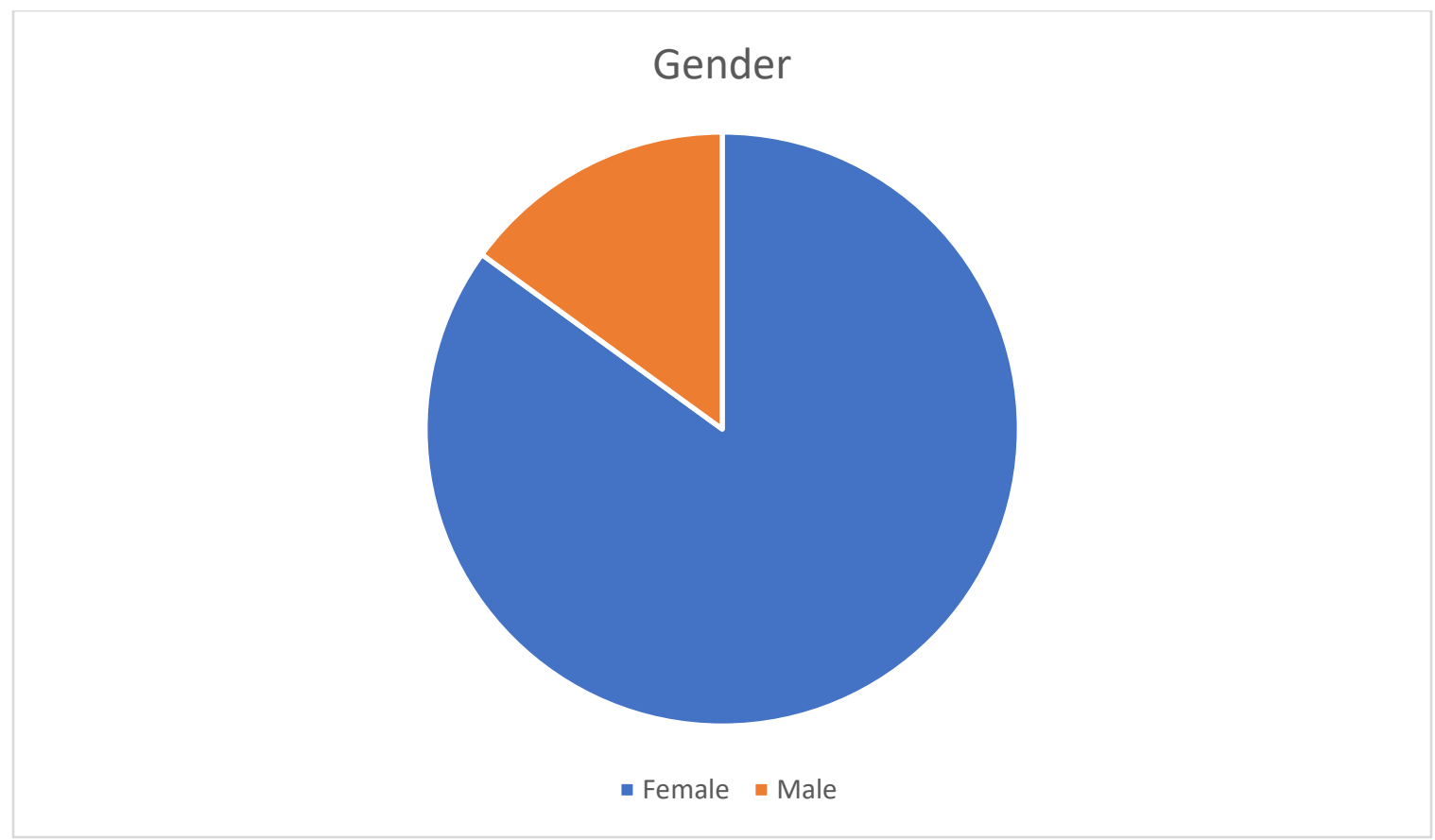

Figure 4.2 Respondents by gender

and language planning of Saami languages: women form a large majority. There are some practical explanations for this. Many male Saami work full-time as reindeer herders, and some others for instance as builders commuting from Finland to Norway. Reindeer herders can't take a year off for language studies. Women often spend more time at home, or working in public services for example, which makes it much easier for them to attend a language course. However, there are other reasons for this too, linked to the history, values and ideologies of each community. Aikio pointed out as early as 1988 that quite often it is the mother of the family who studies a Saami language, even when that mother is a Finn and the father is a Saami. According to Aikio, it seems to be much easier for a person coming initially from outside the community to study and use the language, because of the lack of 'an innate load of a taboo prohibiting Saami language' (Aikio, 1988: 312).

In most cases, participating in a year-long intensive language course requires arrangements to be made, economic sacrifices and hard work. There are several forms of financial support for full-time study in Finland, but in the case of adults, often with family, this support is not enough to live on, so many students need savings, loans or extra work. The Saami Language Act 2003 in theory enables studies of a Saami language with full salary for people working in public services, but the annual budget for this purpose is meagre, and only some get this opportunity ${ }^{i v}$. One of my interviewees described his/her preparations for an economically tight study year:

I had quite a good salary [when living] in the south, and I tried to save like a thousand euros per month so that I would manage. And then I sold all my shares that I had ever bought, everything like that I sold.

Another reported how during the first half of the year (s)he had to work evenings and weekends to manage financially. In the school until 2 pm, working from 3 pm to 9 pm, a couple of hours with 
homework assignments and in the morning to the school. In the end (s)he couldn't cope like that, but with some new apartment arrangements (s)he could stop working and concentrate on studying.

All the teachers I interviewed emphasized that only people with a strong motivation attended the course. Not everybody is capable for it. One teacher summed it up:

If you are going to spend a whole year studying as an adult, you have to make some kind of arrangements for it. It shows motivation. I hear a lot of excuses like one is not ready and not admitting the thought that there's a piece of me missing. Because at the point when you come to take your language back, you have admitted to yourself that you're not whole, you're not like complete, a complete person.

Not all the participants on these courses, however, were taking back their own or heritage language; a remarkable proportion of the students were Finnish. Of the 85 respondents 38 reported Finnish as their primary ethnic identification, whereas 32 identified as primarily Saami. The remaining 15 did not want to define their identification and were unwilling to answer or reported an alternative ethnic identity. This number may partly reflect a heated debate which has been going on lately in Finland, about how and by whom Saaminess should be defined, and the fact that ethnic boundaries are always ambiguous, in Saami lands as in the rest of the world (see for instance Sarivaara et al., 2013). Nevertheless, the proportion of Finns among new speakers of Saami languages must be considered substantial. My study on revitalization of the Aanaar Saami language (Pasanen, 2015) shows that during the approximately 20 years of revitalization, Aanaar Saami has become a prestige language at the local level, among both Aanaar Saami themselves and others.

The most often mentioned motivation for language learning in my data was, however, reclamation of one's own language or heritage language. The next most often chosen alternatives were a widening of labour market prospects, a general interest in language and the wish to support Saami-speaking communities. The revitalization and language development policies in Finland have reached a stage that many Indigenous peoples and minorities around the world can only dream of: knowing Saami language is a great advantage in the labour market. This of course is relevant mostly only in the Saami area, and even there definitely not for all professions. For instance, in the fields of media, health care, early childhood education and basic education, there are better perspectives for employees with Saami language skills, not to mention jobs directly linked to language and language planning, like making teaching materials.

Students on the courses were quite heterogeneous in relation to education, age, ethnic identification and motivation, but typically new speakers were youngish women. A lack of the men in the fields of learning and reviving Saami languages is well known, and usually commented on with humour ('Well yeah, women rule as usual'). Not even the teachers I interviewed could find good explanations for the phenomenon they all recognized. This is a very sensitive issue to discuss, linked to history, livelihoods, gender roles and expectations, attitudes toward educational institutions and so on. One of my female interviewees said, when discussing the roles of the parents in terms of the Saami language:

I do feel tired of being just such an endless source; like, I have to carry everything, even a foreign language. 
According to my data, there were roughly two main types of motivation for attending the year-long intensive language course: reclamation of the heritage language; and 'other reasons'. All the interviewed teachers saw the variety of motivations in the classroom positively. They also viewed as favourable the presence of Saami and non-Saami students in the same group. Diversity made the groups interesting and challenging, and it was healthy for everybody to share thoughts and feelings of their classmates from different backgrounds. The students also taught each other, about the language, about the history and emotions behind it, and they definitely taught the teacher as well. According to the teachers, Saami speakers are needed nowadays in so many fields that there's room for very different people. A rational motivation, like widening labour market prospects, was totally acceptable, as was learning the language of a great-grandmother without any concrete plans to do anything with the language.

\section{Life with a New Language}

In the survey data, $42 \%$ of the respondents reported the daily, active use of Saami language in their life, while $38 \%$ selected the alternative referring to active but not daily use of the language, $16 \%$ reported that they used Saami seldom, and $4 \%$ not at all (Figure 4.3). There were differences between different groups of respondents. New speakers of Aanaar Saami more often reported active daily use than new speakers of the other two Saami languages. Respondents identifying primarily as Saami reported active, daily use more often than respondents with other ethnic identifications.

How widely have new speakers been able to take a Saami language into use in their work (Figure 4.4)? Sixty-six of the 85 respondents answered indicated that they were able to define their work history rather clearly after the course year. Fifty-three percent responded that they had started a new job in which they could use Saami language. Twenty-three percent

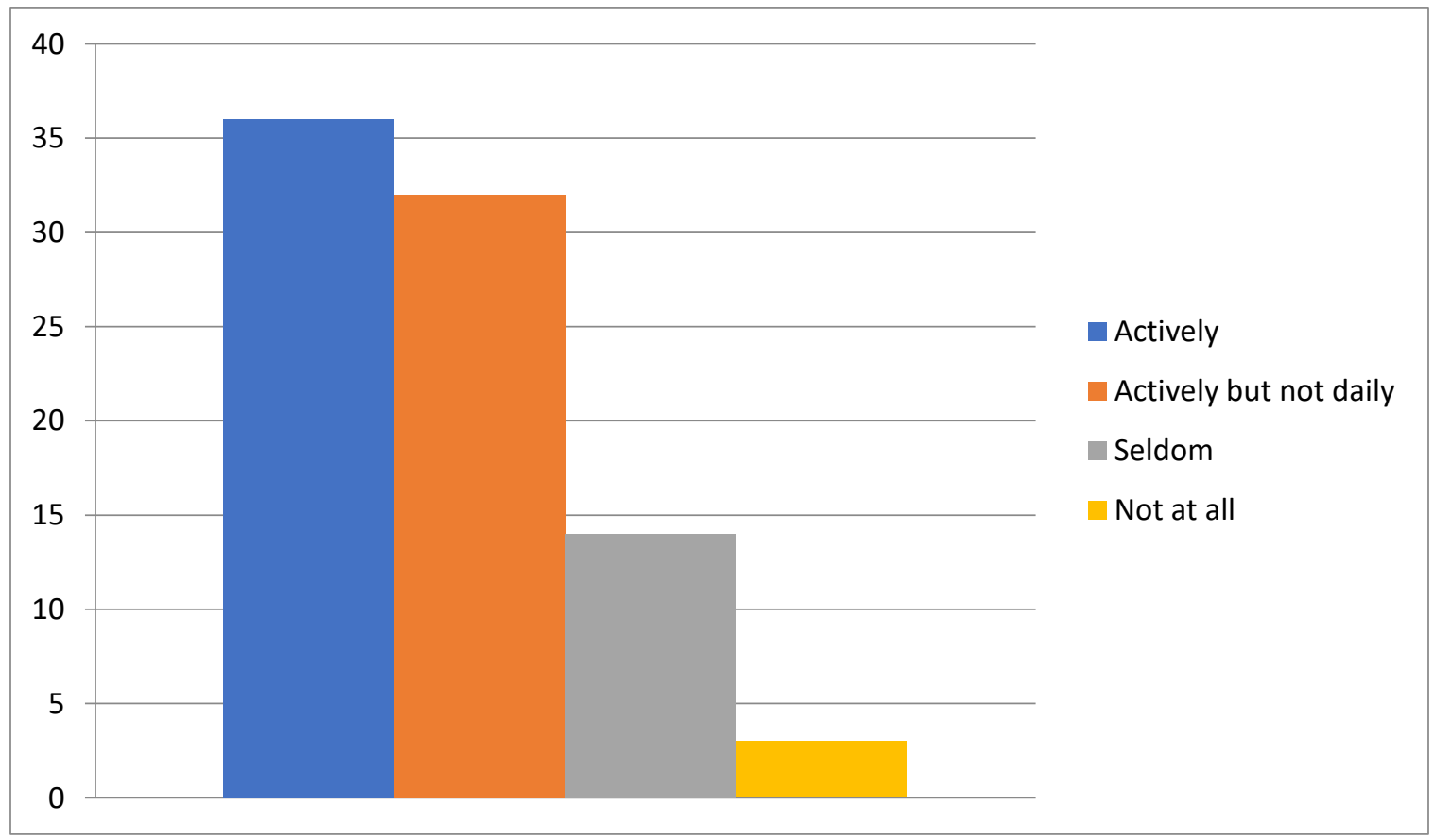


Figure 4.3 Frequency of use of the Saami language at the time of the survey: Numbers of respondents

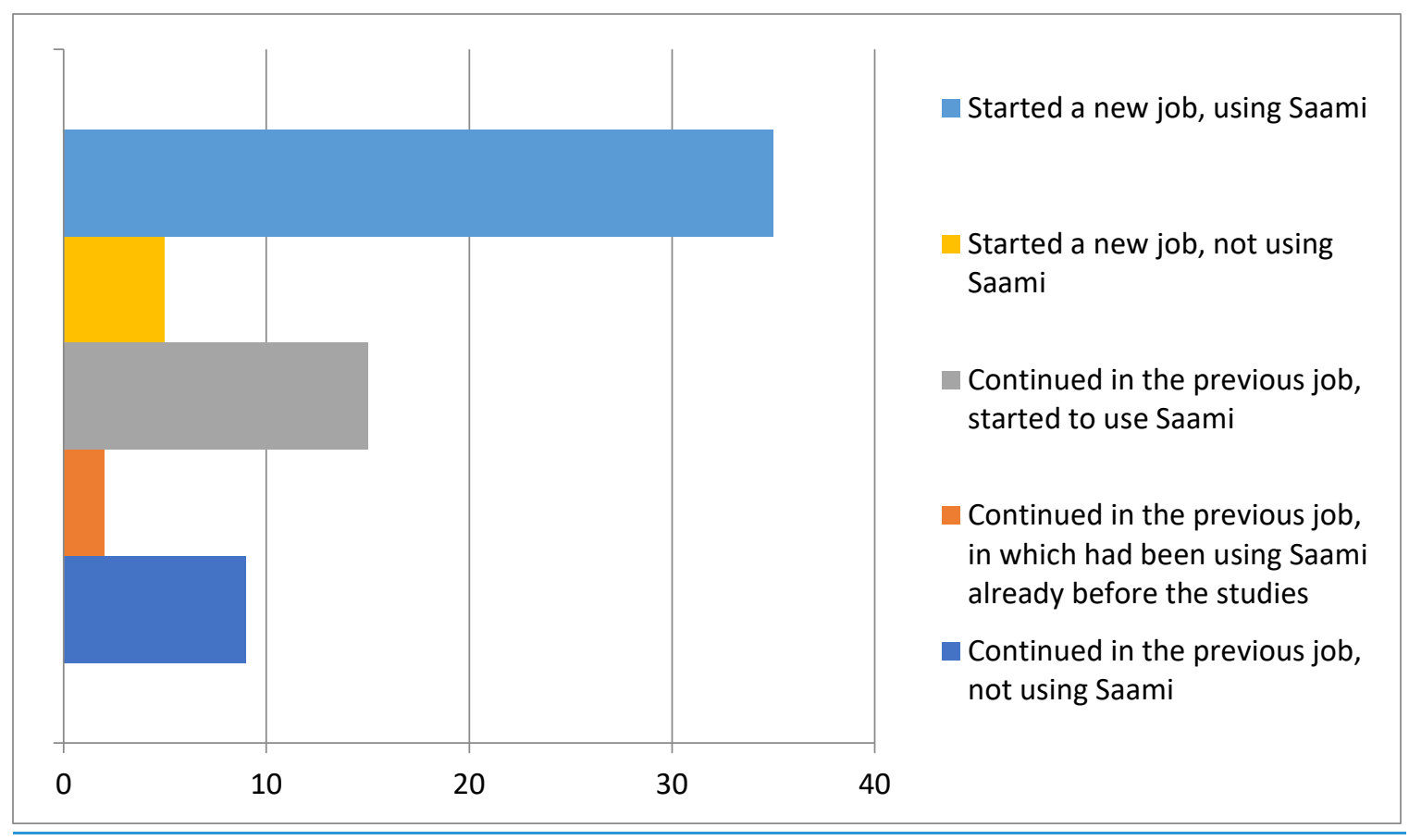

Figure 4.4 Employment and language after Saami language studies: Numbers of respondents

had continued in their previous work but had started using Saami language there. Others continued in their previous work without the possibility to use a Saami language, or had started a new job without a Saami language, or had continued in the work in which they had been speaking a Saami language before they took the course. Over the years, these courses had seen a couple of native speakers, or people with previous language skills, willing to become literate, so the last option also exists. Among the new speakers of all three Saami languages, the most often chosen alternative was beginning a new job with a Saami language. Out of 66 respondents to this question, in 50 cases the course in a Saami language had resulted in a job in which a Saami language was used. This must be considered a very encouraging sign of the impact of intensive courses in Saami languages in the domain of labour.

The vast majority of working-age speakers of Aanaar and Skolt Saami are new speakers, which means that they are found in all professions in which Skolt or Aanaar Saami languages are used. This is not quite the situation in the case of North Saami, but there are also many professionals who have learned North Saami through this course. In my doctoral thesis (Pasanen, 2015: 168-169) I listed about 30 employees using Aanaar Saami as the main language or one of the main languages in their work, of whom only a few had learned Aanaar Saami in their childhood. They were working as employees in language nests, in the Saami Parliament, at primary and secondary schools in the municipality of Aanaar, on Saami radio, at the Siida Saami Museum and in the Nature Centre, Saami Education Institute in Aanaar, as well as at the Giellagas Institute of the University of Oulu. There are also some new speakers of Saami languages in dental and elder care, as well as in other public services. However, it must be mentioned that these services, sanctioned by the Saami Language Act, are not organized in the three Saami languages in all the munici palities, and generally there are many difficulties in implementation (Pasanen, 


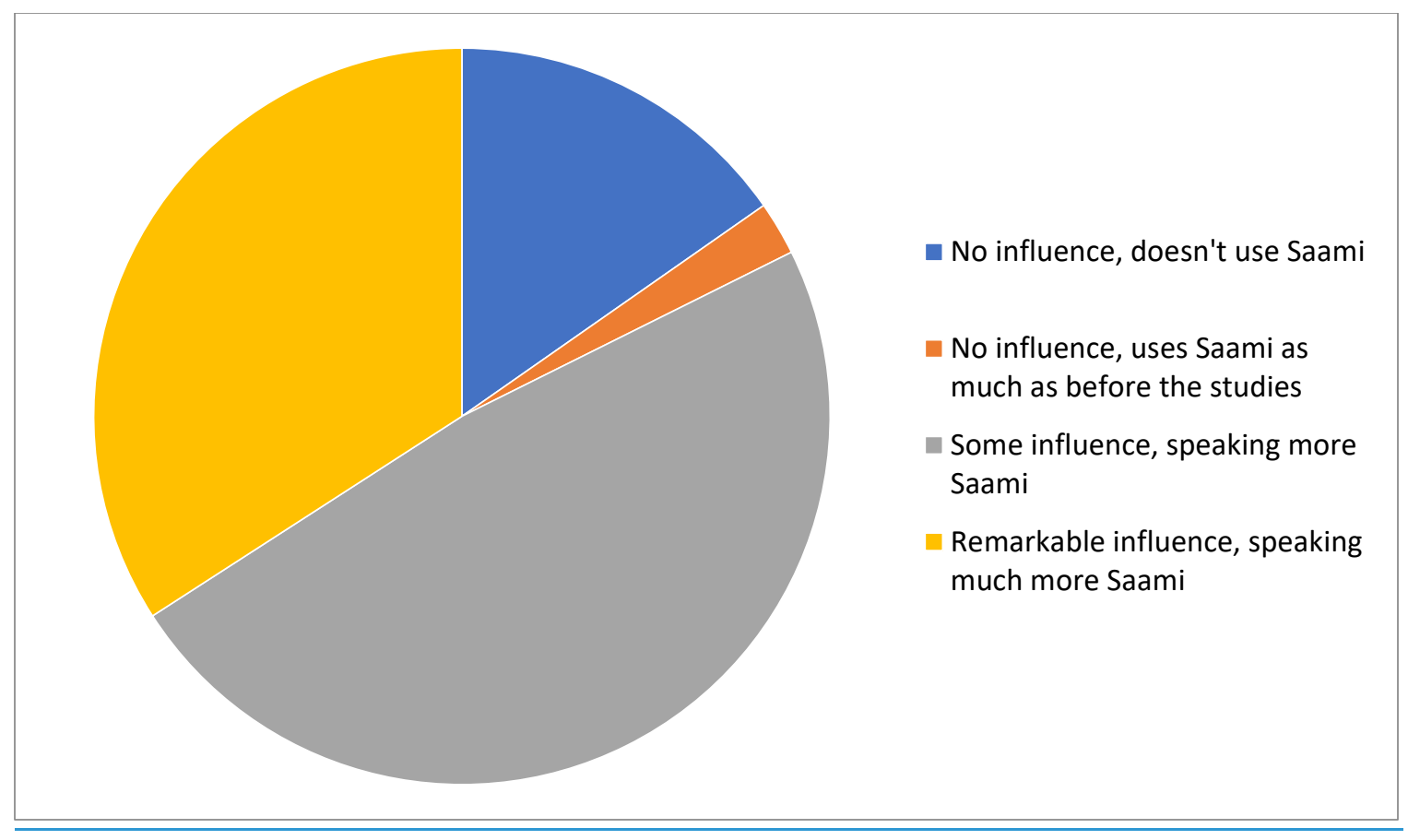

Figure 4.5 Influence of the Saami language studies on the use of a Saami language in social networks

2016). This is often stated as one main argument for the year-long language course: implementation of the legal linguistic rights of the Saami will not proceed without instruction of new speakers.

Next I turn to the use of a Saami language in social networks, that is, language use with friends and neighbours, and so on (Figure 4.5). Fortyeight percent of the respondents reported that they had started to speak a Saami language more often in their social networks. Thirty-four per cent reported a considerable increase in using Saami language. The rest, according to their responses, were using Saami as much as or as little as before their studies, or were not using it at all. More respondents with a Saami identity reported greater use in their networks, as did new speakers of Aanaar Saami relative to speakers of the other two Saami languages.

Intergenerational transmission of Aanaar and Skolt Saami was interrupted almost totally during the post-war decades. Transmission restarted with the language nest activities at the end of the 1990s, and then gradually in some families in which Saami language was chosen as the home language by parents who often had just learned the language themselves. At that time, it was, however, a conscious choice of a couple of individuals. Intensive full-time language education was a huge step forward in the revitalization of both languages, and that is what enabled relinguification of the homes (Fishman, 1991: 26), at least in theory, on a wider scale. Therefore, the following question is essential: to what extent have new speakers of Saami languages started to use a Saami language with their children? In the history of North Saami there is no similar interruption of language transmission, and in many areas the language has been transferred to the children through generations. In some other areas, though, North Saami has vanished or almost vanished, and in Finland this is the case in the southernmost speech area, village of Vuotso and its surroundings (see Aikio, 1988).

Given that intensive adult education in Aanaar Saami started in 2009 and education in Skolt Saami in 2012 , it is still too early to draw strong conclusions about the impact of language education on the 
relinguification of homes. More must be done to find ways to support families of new speakers. Sustainability needs research.

Fifty-one respondents out of the 85 had children, and $57 \%$ of them reported that learning a Saami language had increased their use of it at home to some extent, while $20 \%$ reported about a considerable increase: Saami had become a home language for the family. With respect to the remainder, learning Saami language had not influenced the situation at home, either because Saami had already been spoken or because it still wasn't spoken at all (Figure 4.6).

There were no clear differences linked to ethnic identification or the Saami language selected for study. Out of the 10 respondents who reported taking the Saami language into use as a home language, five had studied Aanaar Saami, four North Saami and one Skolt Saami.

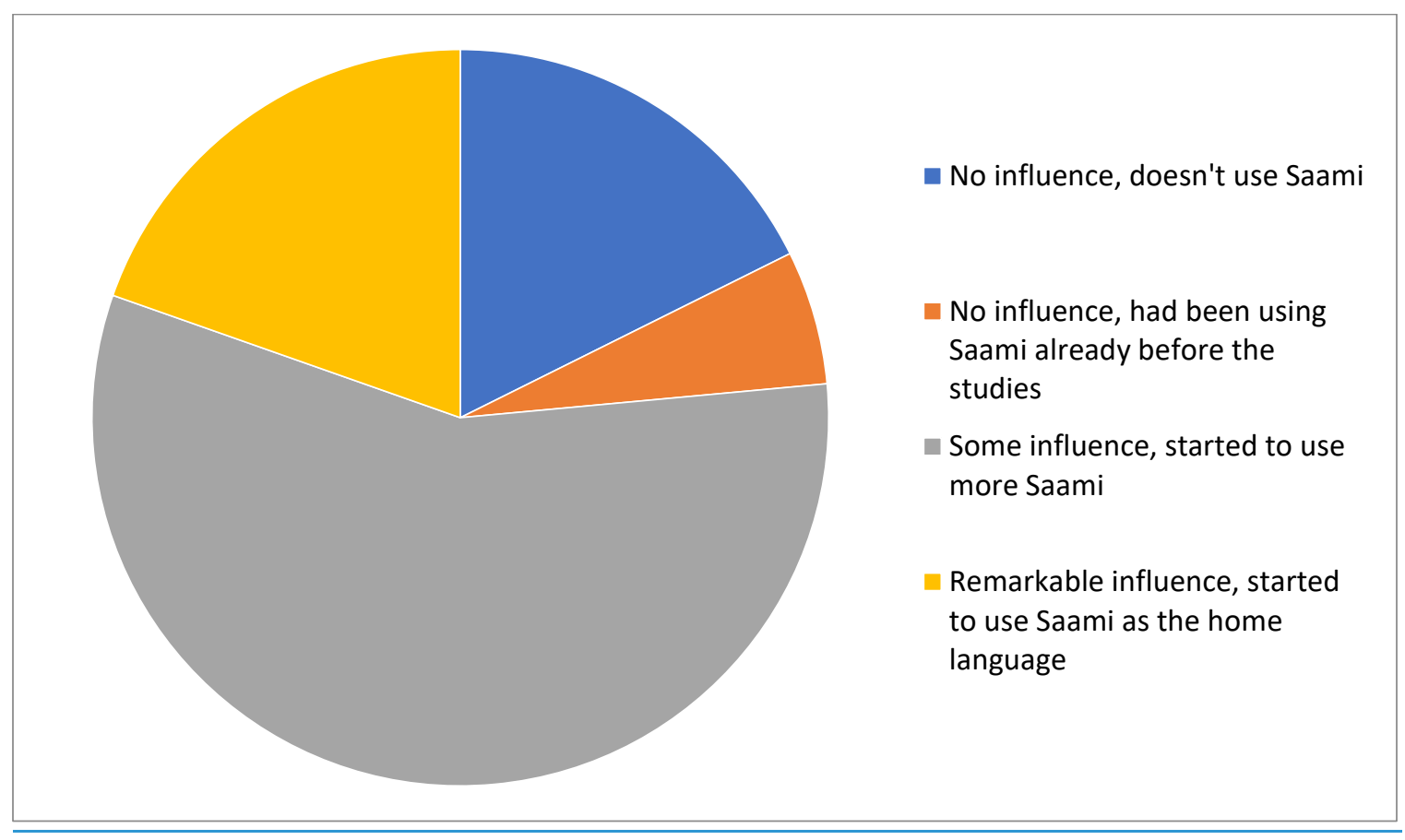

Figure 4.6 Influence of the Saami language studies on the use of the Saami language with the children

My results can be viewed from different perspectives. On the one hand, it is very promising that three-quarters of the respondents with children had increased the use of the Saami language with their children. On the other hand, the alternative 'Affected to some extent. I started speaking more Saami with my children than before', could cover very diverse situations. In some cases, it could mean that occasional use of Saami had increased and was established as a permanent part of the family life. In some cases, it could mean that a parent who hadn't spoken Saami to his/ her children at all had started to use it occasionally, at the level of single phrases for example.

I interviewed five of the respondents who had reported the largest impact of the language learning: having taken a Saami language into use as a home language. Four of them had started to speak exclusively one of the Saami languages to their children, and one had ended up using both Saami and Finnish with the children. Some of them were already parents during the language course, while others had become parents a couple of years after the course. Their situations varied widely in relation to the 
possible Saami language skills of the spouse, and to the process of taking a Saami language into use. It had been a self-evident, gradual process for some, and a result of very conscious, even painful decisions for others. Attitudes of outsiders had varied between positive and supportive, neutral and critical. One new speaker spoke of critical comments heard while she was pregnant:

It was actually quite clear in the beginning, already when I applied for the course, I had the idea that some day - when I have my own children, I could speak Saami to them. And when I got pregnant, I thought of course that I would speak Saami, and I had thought it already before that. But then during my pregnancy it was a little questioned, like, you know, the issue of the language of emotions, which is discussed a lot, that you should speak the language of your emotions or the language that you learned as your first language.

This informant hadn't given up her decision, though. As one supportive factor for the decision she mentioned university lectures I gave on language endangerment and revitalization. During these lectures, examples of similar situations around the world were presented and there was discussion of how new speakers of very small or even sleeping languages, have taken their heritage language into use with their children (Hinton, 2013).

Yeah, it really helped a lot - so I got even more, maybe the kind of support that you can get like this, that I won't ruin the child totally, or ruin my own relationship with her/him.

At the time of the interview, this person had been speaking exclusively a Saami language to her child for approximately one year. She was happy with her choice and was determined to continue speaking only Saami. She felt she was doing the right thing for her child.

What I also thought was, what would [the child] think as an adult, if (s)he knew that mother has worked with the Saami language all the time and spoken and used it, would have been able to speak it, 'why didn't she then speak it to me?'

According to my data, Saami languages seem to access more widely the domains of labour and social networks than the domain of family. However, these domains are incomparable in many ways, since the amount and depth of linguistic contacts in a family and everywhere outside a family are at very different levels. Speaking the language to other adults and transmitting the language to one's own children also demand very unequal resources and efforts.

On the basis of my survey, it seems that a majority of the new speakers with children had increased speaking Saami with them, but only some of them had taken Saami into use as a regular home language. Every word of Saami spoken to a child is a step forward in the current situation. Then again, occasional and symbolic use of a Saami language isn't enough for language acquisition of a child, at least if (s)he doesn't have strong linguistic support from elsewhere: early childhood education in Saami, language nests, education through the Saami language or other adults speaking the Saami language to the child regularly. It is not always under stood by the parents that radical efforts and changes are necessary to reverse language shift. According to Fishman (1991: 236-239, 368-380), parents tend to have expectations of schooling that are far too optimistic when it comes to language acquisition of the children and the revitalization of an endangered language. As far as I can see, language choices with one's children or spouse are not widely discussed in Saami communities. It is the most private choice of individuals, easily loaded with guilt and disappointment in the context of assimilation and revitalization. 
As Dauenhauer and Dauenhauer (1998: 97) point out, 'the paradox of revitalization is that it requires consciousness and planning, and the language lives and is chosen in privacy'.

\section{New Speakers and Old Speakers}

Curricula for the different Saami languages are similar, but there are some differences between them. One of these is connected to the contact between new speakers and native speakers of a Saami language. By native speakers, in this case I mean people who have acquired a Saami language in their early childhood at home. In education in Aanaar and Skolt Saami, an essential role is played by masterapprentice interaction. That interaction means individual contact with (usually) an elder person, who is a first-language speaker of the language in question, and willing to speak the language with the learner or in some cases a couple of learners at the same time. Couples or groups can do whatever they like traditional activities or shopping in the nearest town are both fine - but it has to be done in the Saami language, with Finnish excluded totally.

In the Saami area, this model has been applied to the needs of the first adult education in Aanaar Saami, in 2009-10 (the CASLE project, mentioned above), inspired by the Californian Master-Apprentice Language Learning Program (see Hinton, 2002). A similar method was adapted to become one part of the year-long adult Saami course. However, unlike in California, where the learners meet their language masters at the beginning of their learning process, Saami learners start their journey with the language masters after a couple of months of study, with varying levels of communicative language skills (Olthuis et al., 2013: 40-46, 79-94; Pasanen, 2015: 251-324).

The CASLE project had shown master-apprentice interaction to be a success. Indeed, it became the most important and most liked part of the course according to the feedback from students (Pasanen, 2015: 277-280). Through this instructional approach, students accessed knowledge about language, culture and history, and much more, that would have been impossible to transmit to them in the classroom. Data from the open questions of the survey and the interview material in my postdoctoral research indicate the importance of language masters for the adult learners of Saami languages.

However, master-apprentice interaction hasn't been included in the education of North Saami. This difference is obviously reflected in the responses of new speakers to the question about how the learners had experienced the attitudes of native speakers during the course. Responses refer generally to positive attitudes. Among all 85 respondents, 39\% had experienced very supportive attitudes, and $35 \%$ mainly supportive. Twenty-five percent of the respondents had chosen the alternative 'Varying between different people', and a single respondent had experienced very negative and critical attitudes; the alternative 'Mainly negative or critical' was chosen by none of the respondents. Interestingly, responses of the students of different Saami languages differed considerably. While $73 \%$ of the students of Aanaar Saami had experienced very supportive attitudes. Skolt Saami students had chosen most often the alternative 'Varying between different people', and among the students of North Saami the most common response was 'Mainly supportive'. Also, interestingly, there was no difference worth mentioning between those who identified as primarily Saami and those who identified as primarily Finnish. 
According to the interview data from the language masters of the CASLE project, these elder speakers of the Aanaar Saami language have the same positive attitude toward learners of the language no matter their ethnicity (Pasanen, 2015: 294-297, 307-309). When the interviewer asked about the language masters' thoughts concerning new speakers of Aanaar Saami, two language masters made the following responses:

Language master 1: Well, it is terribly important. There are so few speakers of Aanaar Saami that any amount of new speakers doesn't hurt.

Language master 2: [It was] amazing and nice that nowadays also Finns want to know and learn a Saami language.

Then the interviewer asked whether the masters found it at all weird that nowadays also Finns want to learn a Saami language.

Language master 1: No, not at all, since Finnish people want to learn also English and Russian and so on, which is exactly the same. At least I think so.

Language master 2: Not so weird, when you have been used to it, but back in the 1960s or 1970s it would have been a stranger thought.

The interview material for my unpublished postdoctoral research is in line with these findings. Even if the attitudes of Skolt and North Saami L1 speakers seem to be widely positive towards language learners, there are some factors which may lead to diffidence among the new speakers. In the Skolt Saami community there are native speakers who criticize in public the standardization of the language as not authentic, as well as the competence in the language of new speakers who study a standardized form. For instance, some new speakers working as radio journalists have faced very critical feedback about their language competence. (On the attitudes of the Skolt Saami community and so-called transference of the burden, see Laihi, 2017: 85-95, 125-136.) Then again, in the speech community of the North Saami language, there are still plenty of native speakers, also among younger generations. Therefore, there is no such acute need for new speakers as there is in the case of Aanaar and Skolt Saami, and native speakers and new speakers don't necessarily end up in close contact with each other. This concerns especially those new speakers who do not have Saami relatives (i.e. Finnish speakers of North Saami). Lack of master-apprentice interaction in the curriculum of North Saami education seems to reinforce this problem.

Another question in the survey, referring to the relationship between new and native speakers, was about the identification of the new speakers with the speech community: whether they felt themselves to be active members or outsiders in the community.

Of the respondents, $21 \%$ reported that they identify themselves as active members of the community, and $52 \%$ responded that they feel they belong to the community to some extent, while $15 \%$ felt themselves clearly outsiders in the community, and $12 \%$ did not answer the question (Figure 4.7).

There was quite a clear difference by ethnic identity: respondents with Saami identity felt themselves much more often active members of the 


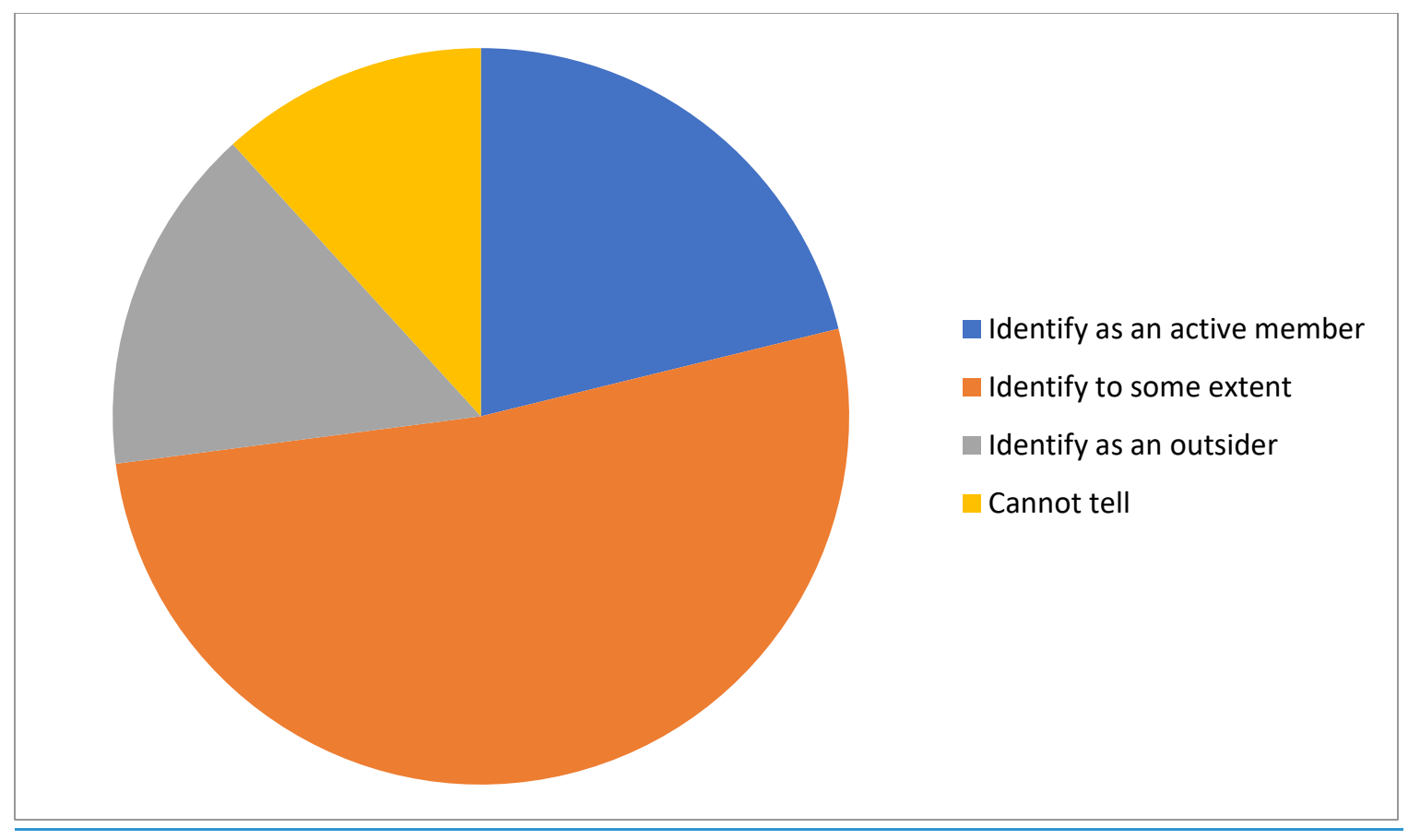

Figure 4.7 Identification of the respondents with the speech community of the Saami language

community in comparison with the respondents with Finnish identity. Differences in Saami language study were, however, even clearer: new speakers of Aanaar Saami identified much more often as active members of the community than new speakers of the two other languages.

Belonging to the community is of course a very subjective experience, greatly depending on one's personality and values. Not everybody has a goal of becoming an active member of a speech community when learning a new language. Staying outside or at the doorstep may be the most natural and positive position for a new speaker. These differences reflect particular differences between the linguistic cultures of the Aanaar Saami and North Saami speakers. If we see linguistic culture as does Schiffman (1996), as an entity with historical, geographic, demographic, social, ideological features and so on behind a certain speech community and situation of a language, the first obvious difference is that North Saami has a lot more speakers than Aanaar or Skolt Saami. It doesn't face such an obvious and acute danger of disappearing. Speakers of North Saami also live in a much wider area, so there is no one particular, concrete speech community as in the cases of Skolt and Aanaar Saami, which are spoken mostly in Aanaar. The fact that there are a lot of young North Saami speakers may counter the fact that a huge part of the people of North Saami origin do not speak the language and that there are not enough speakers in relation to growing needs. As one teacher analysed attitudes of the North Saami speech community:

There isn't the same thought yet that we have to work to get new North Saami speakers. Like, on the Aanaar Saami side and Skolt Saami side, it's totally clear, that, hey, something has to be done.... The perspective is very different in the case of emergency. And maybe speakers of North Saami don't think yet that it's an emergency.

The attitudes of the native North Saami speakers towards new speakers has been referred to in some previous studies. Jonsson and Rosenfors (2017: 57-58) analyse how a North Saami learner brings up 
experiences of the unwillingness of native speakers to speak Saami to a new speaker. Similar experiences appear in my data. One new speaker described the situation as follows:

Interviewee: After all, there were a couple of, a few people I know, in my close circles, who wanted to speak Saami, or they made the choice that they spoke to me, and then it was easy for me to speak to them.

AP: Were there other choices, then, people who didn't want to?

Interviewee: Oh yes, yes, yes, yes.

AP: Which of them are more?

Interviewee: There are more of those who don't want to shift to Saami.

The interviewee continued to ponder that those who had chosen to speak Saami to her/him were usually people who had themselves struggled in their lives with language revitalization and therefore had a wider perspective on these issues.

\section{Discussion}

Language practices of the new speakers play an essential role in the future of Saami languages. In the global context of Saami languages, revitalization might be compared to Māori and Hawai'ian revitalizations. All three revitalization projects share a common history of assimilation, with similar sociolinguistic starting points for revitalization, as well as similar methods and forms of revitalization. All three languages can be learned outside home, in the language nest, mother-tongue-medium education and through intensive language education for adult people. New speakers also form a significant proportion of all speakers of these languages. In the cases of Māori and Hawai'ian, the phenomenon of new speakers has a decades-old history, which means a lot of experience and evidence about impacts of the revitalization compared with Saami languages. The ultimate question is whether the new speakers have started to transmit the language to their own children. How widely have the homes been re linguified? The research on new Saami speakers has only just begun. I am continuing to collect data through interviews and continuing to study the issue in the framework of global research about new speakers, to better understand the processes involved in reversing language shift. As my questions continue to evolve and change with data, the following are important at this juncture:

- Who are those who don't take their language back or try to learn the language of their new home area? Why haven't they considered learning the Saami language necessary or possible for them? How do the men who don't personally participate in learning and reviving Saami languages experience these issues?

- Are there ways to promote a relinguification of homes? What kind of support do the new speakers need to speak Saami to their children? 
-What kind of features lie behind different results of different Saami languages? What are the attitudes of native speakers of the North and Skolt Saami languages towards learners and new speakers? Are there patterns of change as revitalization proceeds?

This chapter began with a quotation from an Aanaar Saami language teacher emphasizing the importance of intensive education for students. Let it end with a short extract from the interview with the previous teacher of the Skolt Saami language, emphasizing the importance of this education for the whole language:

Annika Pasanen: Mitä tämä koulutus on antanut koltansaamen kieliyhteisölle ja kolttasaamelaisille?

Tiina Sanila-Aikio: No, tulevaisuuden. Piste. [nauraa]

Annika Pasanen: What has this education given to the speech community and the Skolt Saami people?

Tiina Sanila-Aikio: Well, the future. Full stop. [laughter]

\section{References}

Aikio, M. (1988) Saamelaiset kielenvaihdon kierteessä. Kielisosiologinen tutkimus viiden saamelaiskylän kielenvaihdosta 1910-1980. Suomalaisen Kirjallisuuden Seuran toimituksia 479. Helsinki: Suomalaisen Kirjallisuuden Seura.

Aikio-Puoskari, U. (2016) Gullos sámegiella! Sámegielaid ealáskahttima buoremus vuogit ja našuvnnalaš politihka linját Suomas, Ruołas ja Norggas. Aanaar: Samediggi \& Sámegiela doaimmahat.

Dauenhauer, N.M. and Dauenhauer, R. (1998) Technical, emotional, and ideological issues in reversing language shift. Examples from Southeast Alaska. In L.A. Grenoble and L.J. Whaley (eds) Endangered Languages: Current Issues and Future Prospects. Cambridge: Cambridge University Press.

Fishman, J. (1991) Reversing Language Shift: Theoretical and Empirical Foundations of Assistance to Threatened Languages. Clevedon: Multilingual Matters.

Hinton, L. (2002) How to Keep Your Language Alive: A Commonsense Approach to Oneon-One Language Learning. Berkeley, CA: Heyday Books.

Hinton, L. (ed.) (2013) Bringing Our Languages Home: Language Revitalization for Families. Berkeley, CA: Heyday Books.

Huss, L. (1999) Reversing Language Shift in the Far North: Linguistic Revitalization in Northern Scandinavia and Finland, Studia Uralica Uppsaliensia 31. Uppsala: Acta Universitetis Uppsaliensis.

Jonsson, C. and Rosenfors M. (2017) 'I have struggled really hard to learn Sami': Claiming and regaining a minority language. International Journal of the Sociology of Language 248, 49-71.

Laihi, T-M. (2017) Skolt Sámi language and cultural revitalization: A case study of a Skolt Sámi language nest. Master's thesis. University of Helsinki. Available at https:// 
helda.helsinki.fi/bitstream/handle/10138/193650/Laihi\%20sosiaali-\%20ja\%20

kulttuuriantropologia.pdf?sequence=2 (accessed 15 July 2019).

Olthuis, M-L., Kivelä, S. and Skutnabb-Kangas, T. (2013) Revitalising Indigenous Languages: How to Recreate a Lost Generation. Bristol: Multilingual Matters.

O’Rourke, B., Pujolar, J. and Ramallo, F. (2015) New speakers of minority languages: The challenging opportunity. Foreword. International Journal of the Sociology of Language 231, 1-20.

Pasanen, A. (2015) Kuávsui já peeivičuovâ. 'Sarastus ja päivänvalo'. Inarinsaamen kielen revitalisaatio, Väitöstutkimus. Uralica Helsingiensia 9. Helsinki: Suomalais-ugrilainen Seura \& Helsingin yliopisto. Available at http://www.sgr.fi/uh/uh9.pdf (accessed 15 July 2019).

Pasanen, A. (2016) Saamebarometri 2016. Selvitys saamenkielisistä palveluista saamelaisalueella. Sám giellabaromehter 2016. Čielggadus sámegielat bálvalusain sameguovllus. Selvityksiä ja ohjeita 39/2016. Helsinki: Oikeusministeriö. Available at http://julkaisut. valtioneuvosto.fi/bitstream/handle/10024/78941/OMSO_39_2016_Saamebaro_120s. pdf?sequence=1\&isAllowed=y (accessed 15 July 2019)

Rasmus, M. (2008) Bággu vuolgit, bággu birget. Samemánáid ceavzinstrategiijat Suoma álbmotskuvlla ásodagain 1950-1960-logus, Publications of the Giellagas Institute 10. Oulu: Giellagas-instituhtta.

Sarivaara, E. (2012) Statuksettomat saamelaiset. Paikantumisia saamelaisuuden rajoilla. Dieđut 2. Guovdageaidnu: Sámi Allaskuvla.

Sarivaara, E, Uusiautti, S. and Määttä, K. (2013) The position and identification of the nonstatus Sámi in the marginal of indigeneity. Global Journal on Human Social Science Arts and Humanities 13 (1). Available at https://socialscienceresearch.org/index.php/ GJHSS/article/view/535/482 (accessed 15 July 2019).

Scheller, E. (2011) The Sámi language situation in Russia. In R. Grünthal and M. Kovács (eds) Ethnic and Linguistic Context of Identity: Finno-Ugric Minorities, Uralica Helsingiensia 5 (pp. 79-96). Helsinki: Helsingin yliopisto \& Suomalais-Ugrilainen Seura.

Schiffman, H.F. (1996) Linguistic Culture and Language Policy. London: Routledge.

Seurujärvi-Kari, I. (2012) Ale jaskkot eatnigiella. Alkuperäiskansaliikkeen ja saamen kielen merkitys saamelaisten identiteetille. Helsinki: Helsingin yliopisto.

UNESCO (2010) Atlas of the World's Languages in Danger. Paris: UNESCO. Available at http://www.unesco.org/languages-atlas (accessed 15 July 2019).

\section{Notes}

\footnotetext{
'Aanaar is the name of the municipality in the Aanaar Saami language. The Finish equivalent is Inari. This chapter uses only Aanaar Saami. Aanaar Saami is the name of the language.

ii The Finnish constitution can be seen online at https://www.finlex.fi/fi/laki/ kaannokset/1999/en19990731.pdf (accessed 15 July 2019).
} 
iii Indigenous and Tribal Peoples Convention, at https://www.ilo.org/dyn/normlex/en/f?p $=$ NORMLEXPUB:12100:0::NO::P12100_ILO_CODE:C169 (accessed 15 July 2019).

iv The Sámi Language Act (Saamen kielilaki) 1086/2003 is available at http://www.finlex. fi/en/laki/kaannokset/2003/en20031086 (accessed 15 July 2019). 